\title{
15 An analysis of the box office success of Wolf Warrior 2 (2017)
}

\author{
Chao $\mathrm{Yu}$
}

\section{How Wolf Warrior 2 became the most popular film of 2017}

The year 2017 was the 90th anniversary of the establishment of the Army of the People's Republic of China. This is the army that serves its people and is directly led by the Party. Chinese national cinema in 2017 was also full of soaring and passionate heroism. The military action film Wolf Warrior 2 created a miracle at the domestic box office at an astonishing speed since its remarkable release. Leng Feng, a tough man in the film, is both patriotic and romantic, becoming the symbolic image of a "hero." Wolf Warrior 2 is the milestone or even the benchmark of domestically produced films, because military action films were never a popular genre in the Chinese film market before, and now, with the success of Wolf Warrior 2, this genre has become the "engine" of the box office.

Wolf Warrior 2 was released on July 27, 2017 in domestic major cinemas and exceeded 100 million yuan in 4 hours. The box office was over 200 million yuan the next day and reached 310 million on July 29. The total box office in the first three days exceeded 600 million yuan. On July 31, the box office reached 1 billion yuan, which broke the record set by the film The Mermaid (Stephen Chow, 2016) which exceeded 1 billion yuan in 92 hours. Wolf Warrior 2 became the film whose box office reached 1 billion yuan the fastest. Riding on the effects of good acclaim, Wolf Warrior 2 continuously renewed the single-day box office record, which was a phenomenon that had never before happened in the history of Chinese film, and finally it became the box office champion of 2017 with a box office performance of 5.68 billion yuan, creating a box office legend in Chinese film history. The numbers of moviegoers of Wolf Warrior 2 are more than 100 million, which surpassed the 91.587 million moviegoers for The Mermaid, setting a new record for the highest number of cinema admissions on the domestic film market. The global box office of Wolf Warrior 2 is US\$870 million, of which the Chinese box office accounts for 98 percent. It is the only non-English film in the top 100 global box office ranking.

With such positive reviews and word of mouth reputation, Wolf Warrior 2 was given 7.2 by voters on the Douban platform and 9.7 on MaoYan's 
Movie platform, which was slightly below the most surprisingly popular film Dangal in 2017, whose grade was 9.8. Wolf Warrior 2 won many awards, including Best Picture at the Golden Crane Award during the Chinese Film Week; Excellent Work Award in "Five One Projects of Spiritual Civilization Construction"; Best Picture Award at the China ASEAN Film Festival, and Asia Popularity Award at the Second Macao International Film Festival and Award. Wolf Warrior 2 won My Favorite Feature Film Award, and Janson Wu won My Favorite Actor Award at the Second National Primary and Secondary School Students Film Week. Many students were inspired by the film to be as responsible, accountable and courageous as Leng Feng. All those awards and approvals showed that the influence of Wolf Warrior 2 was so widespread and significant that it was worthy of the title: "the most popular and phenomenal film of 2017."

Exploring the overseas film market is always the goal of Chinese national cinema. Cooperating with the European Times and the five most influential German mainstream cinema chains, Cinemaxx, Kinopolis, Cinestar, Cineplex and UCI, Wolf Warrior 2 was screened in German cinemas on September 16, 2017. The viewing rate of the film was approximately 70 percent on its firstday debut and it was screened in more than 30 cities hereafter. CMC, the overseas release party, obtained the publishing rights of many European countries including Germany, Austria, the Netherlands and Belgium. This marked a good beginning for Chinese films to enter the European market. Wolf Warrior 2 was also shown in Japanese art cinema chains on a minor scale, and the mainstream cinema chains, including Toho Company, later announced that the film would be screened across the country from January 1, 2018.

\section{The box office success of Wolf Warrior 2}

The reason why Wolf Warrior 2 was the miracle in the history of the Chinese box office is that it happened at the right time, at the right place and with the right people. In order to foster the development of domestic films, the previous State Administration of Press, Publication, Radio, Film and Television had issued a regulation that Domestic Film Protection Months would be between July to August every year. During this period, domestic films would receive complete support from nationwide cinema chains and importing foreign blockbuster films would not be encouraged. There was only one Hollywood film showing, Despicable Me 3, when Wolf Warrior 2 was showing. Compared with other domestic films such as The Founding of an Army, Our Time Will Come, The One, Father and Son, and Our Shining Days, Wolf Warrior 2 undoubtedly had an advantage at the box office. Without any competition from foreign films and with the prominent film quality, the popularity of Wolf Warrior 2 was unstoppable. Also, 2017 was the 90th anniversary of the PRC's Army being inaugurated and Wolf Warrior 2 was released on July 27, 2017, which made it a gift for the celebration of Army Day by showing its love for the People's Liberation Army. This was also the reason why moviegoers chose 
to watch this film. Besides, the incident when the Indian military invaded the non-disputed area in Chinese Tibet in June had also stimulated patriotism among people, and to some extent excited them with the passion and expectation for this film.

Another important factor that contributed to the success of Wolf Warrior 2 was the delay in its removal from cinemas. On September 18, the China film group cooperative notified its nationwide cinema chains that the copyright screening period for Wolf Warrior 2 would be prolonged for one month to October 28 (Table 15.1). This gave the film three months total screening time, which contributed to the moviegoers' passion for Wolf Warrior 2, enabling some fans to see the film several times.

Some 54 percent of Wolf Warrior 2's audiences are female viewers. According to the nationwide average data accounts, their numbers are slightly higher than those of male moviegoers. In terms of age background, 35.9 percent of moviegoers are between 20 and 24 years old and 25.9 percent

Table 15.1 Statistics of domestic box office of Wolf Warrior 2

\begin{tabular}{|c|c|c|c|c|}
\hline Week & $\begin{array}{l}\text { Number } \\
\text { of people } \\
\text { per show } \\
\text { (person) }\end{array}$ & $\begin{array}{l}\text { Single-week } \\
\text { box office } \\
\text { (million) }\end{array}$ & $\begin{array}{l}\text { Total box } \\
\text { office } \\
\text { (million) }\end{array}$ & $\begin{array}{l}\text { Days on } \\
\text { show }\end{array}$ \\
\hline $\begin{array}{l}\text { First week } \\
\text { July } 24 \text { to July } 30\end{array}$ & 68 & 99681 & 99691 & 4 \\
\hline $\begin{array}{l}\text { Second week } \\
\text { July } 31 \text { to August } 6\end{array}$ & 62 & 217126 & 316799 & 11 \\
\hline $\begin{array}{l}\text { Third week } \\
\text { August } 7 \text { to August } 13\end{array}$ & 41 & 140241 & 457025 & 18 \\
\hline $\begin{array}{l}\text { Fourth week } \\
\text { August } 14 \text { to August } 20\end{array}$ & 26 & 56448 & 513467 & 25 \\
\hline $\begin{array}{l}\text { Fifth week } \\
\quad \text { August } 21 \text { to August } 27\end{array}$ & 17 & 26080 & 539545 & 32 \\
\hline $\begin{array}{l}\text { Sixth week } \\
\quad \text { August } 28 \text { to September } 3\end{array}$ & 16 & 17194 & 556738 & 39 \\
\hline $\begin{array}{l}\text { Seventh week } \\
\quad \text { September } 4 \text { to September } 10\end{array}$ & 7 & 5564 & 562302 & 46 \\
\hline $\begin{array}{l}\text { Eighth week } \\
\text { September } 11 \text { to September } 17\end{array}$ & 6 & 2289 & 564591 & 53 \\
\hline $\begin{array}{l}\text { Ninth week } \\
\text { September } 18 \text { to September } 24\end{array}$ & 6 & 1197 & 565788 & 60 \\
\hline $\begin{array}{l}\text { Tenth week } \\
\text { September } 25 \text { to October } 1\end{array}$ & 5 & 619 & 566407 & 67 \\
\hline $\begin{array}{l}\text { Eleventh week } \\
\text { October } 2 \text { to October } 8\end{array}$ & 20 & 1029 & 567437 & 74 \\
\hline $\begin{array}{l}\text { Twelfth week } \\
\text { October } 9 \text { to October } 15\end{array}$ & 6 & 210 & 567467 & 81 \\
\hline
\end{tabular}

Source: China Box Office: www.cbooo.cn/. 
are between 25 and 29 years old. According to the analysis from the professional data of MaoYan Movie, the white-collar class (33.1 percent) and students (14.2 percent) make up the majority of cinema admissions for this film. According to the statistical data, the first-tier cities, such as Beijing, Shanghai, Guangzhou and Shenzhen, where the middle class is the dominant class, account for only 19 percent of box office; however, the third- and fourth-tier cities where the blue-collar working class and ordinary workers are the majority account for 40 percent and they have contributed significantly to Wolf Warrior 2's box office success. There was a common characteristic among the top ten box office Hollywood films in China in 2017 such as $x X x$ : Return of Xander Cage, The Fate of the Furious, and Transformers: The Last Knight. The leading characters in those films are all presented as showing strong individualistic heroism. The Indian film Dangal praises the aspirations of lower-class people who achieve great dignity through their undying efforts. The social classes of the moviegoers for Dangal are similar to those of Wolf Warrior 2. They come from third- or the fourth-tier cities, and they were the foundation of the success of Wolf Warrior 2's box office. In Wolf Warrior 2, Leng Feng, a courageous man with principles and justice, is a hero whose military rank and identity have been removed. He is humorous, unrestrained, self-mocking, enthusiastic about football, and keen to exhibit his muscles. This unconventional image of the hero has greatly overturned our traditional concept of "heroes." The story of an ordinary man becoming a hero by saving many people's lives created strong resonance among blue- and white-collar workers. Eventually they contributed significantly to the box office.

\section{The value of IP: intellectual property manifested in scripts}

Jason Wu moved from being an actor to writer/director and film producer with Wolf Warrior 2. Only by having more and more Chinese film projects as intellectual property (IP), can the Chinese film industry truly develop and compete with Hollywood. Luckily, Jason Wu succeeded with Wolf Warrior and Wolf Warrior 2. The original meaning of IP is the ownership of knowledge (property). From the commercial and capital perspective, with the extension of the connotation, IP is the multi-development of cultural industry products. The Wolf Warrior series is Jason Wu's original works, and now can be further adapted into a TV series, games, etc. So, it can be safely considered as IP. The Wolf Warrior project is almost a brand, and has won recognition of moviegoers as an original IP with its production team focusing on the development of original content. It is considered the masterpiece of the military genre. Different from ethical films, romantic dramas, comedy, and the traditional action genre, the setting of the storyline is always overseas which successfully brought moviegoers visual beauty and exciting exotic sceneries. The characterization of the film is so innovative that the character Leng Feng has become the symbol of the Chinese hero, while some moviegoers even think that Jason $\mathrm{Wu}$ is the wolf warrior in real life. The success of Wolf Warrior 2 
as China's champion of the box office benefits significantly from its favorable reputation and prominent film quality as well as the continuous refinement of its scriptwriting over four years. The background story of Wolf Warrior 2 is set in the evacuation of overseas Chinese citizens. Similar background stories based on the real event of the evacuation of overseas Chinese include the robbery in the camps of Libya in 2011, the civil war in Monnai in 2015, the earthquake in Nepal, the earthquake in New Zealand in 2016 and the fires in Israel. The original intention of the Wolf Warrior series is to provide people all over the world with an opportunity to know about the Chinese military, including their wisdom, courage, kindness and responsibility. It tries to exhibit the action and image of a strong China in the face of world disasters and crisis. Different from Wolf Warrior, Leng Feng in Wolf Warrior 2 is no longer a military man as he has had to retire from the service because he beat up local gangsters who tried to destroy and pull down innocent people's houses. But in his heart and soul, the blood of a soldier never stops running. He never forgets his inner duty, undertaking more responsibilities to protect his compatriots as well as everyone who is suffering from war.

Based on Wolf Warrior 2, we can conclude that the essential factors that contribute to the success of a film include a thrilling storyline, persistent efforts at style in the production period, and cultural connotations that comply with mainstream values. With the advantage of IP, we can expect more work from the Wolf Warrior series. At the end of Wolf Warrior 2, the viewer is left with a cliff hanger, letting us believe and hope that Wolf Warrior 3 will triumphantly return in the near future.

\section{A cinematic feast of international blockbuster standard}

The action design has always been the advantage of Chinese action films, and the action scenes in Wolf Warrior series are remarkable. Compared with Wolf Warrior, Wolf Warrior 2 has upgraded its production value with a broader international horizon. It is international because the setting of the story is abroad. Leng Feng, a retired military man from the special corps who goes to Africa to look for the woman he loves, unexpectedly is given an order in a critical situation to save unarmed Chinese civilians and fight ruthless villains, which puts him in a drastic situation. The plot of the story is based on the classic Hollywood narrative. It develops from a state of peace (Leng Feng's daily life in Africa) to a crisis (war and virus), and from crisis to the victory of breaking through the encirclement. In the meanwhile, love (the female doctor's kiss) and humor ("a spoilt brat" who is in charge of relieving the tension of the plot) run through the whole storyline. The film crew has an international team with members from 26 countries. The action director is Sam Hargrave from the Captain America series, and Frank Grillo, who plays the main villain Big Daddy in Captain America. There is also the underwater photography crew from Pirates of the Caribbean. Leng Feng's enemies are upgraded from a bunch of mercenaries to a rebellion army with organizational structure. 
There are not only female snipers but also professional wrestlers and firearms experts among the villains. The variety of crew members and characters offers the chance of showing remarkable combat scenes in the film. Regarding film genre, the Wolf Warrior series could be classified as "military action film" which combines action with intense war battle scenes. Wolf Warrior 2 is full of action scenes, such as the 6-minute underwater long-take combat scene; hanging on to a racing car with single-arm scene, a fight scene in a slum; "parkour" movements with a high degree of difficulty in the Chinese-owned factory, etc. The most amazing scene is the tank battle, which is the climax of the film. This might be considered the "tank version" of Fast and Furious. The tank chase and driving scenes between Leng Feng and the rebellion army surprised moviegoers with a brand-new form of tank battle.

Leng Feng escaped before the tank exploded while the "spoilt brat" Zhuo Yifan gets under the tank to dangerously place an iron hook. Leng Feng and the veteran He Jianguo make use of the advantageous terrain and special mechanical equipment to overturn the tank driven by Old Daddy. The ingenious use of the equipment and surroundings makes this a scene of human triumph against the battle with the tank. Finally, Old Daddy has to come out from the tank and confront Leng Feng face to face. The battle ends with a thrilling, exciting bare hands combat scene. By changing the rhythm and pace of the action scenes, the film creates an emotional wave of tension which raises strong and breathtaking feelings in the moviegoers. During shooting, in order to achieve realistic action scenes, all scenes involving explosions are designed to model real explosions in war. This level of realistic war scene also set a record in Chinese film production history. Tens of thousands of bullets, hundreds of tanks and the latest Chinese helicopters were used in the real combat shooting of the film. The crew blasted hundreds of types of equipment including an airplane, two 20-ton tank models, and approximately 100 cars. It is this huge investment that has ensured the extraordinary visual and audio effects of Wolf Warrior 2.

\section{Cooperation ensures the extraordinary quality of the film}

A successful film needs not only an exciting storyline and magnificent action scenes but also the devotion of the actors. To obtain the most realistic scenes for the story, the crew of Wolf Warrior 2 went to Africa twice during preproduction where they were robbed a few times. Besides the difficult living environment, the crew also suffered from the harsh natural conditions. They hiked for hours in the snow with temperatures more than 10 degrees below zero, and were attacked by poisonous spiders. Jason Wu was dragged away by the ocean current at a speed of 15 meters per second when playing the diving scene from the deck, 13 meters above the water. To complete the stunning underwater action scenes, both the actors and crew members did not take any respirators or oxygen bottles and had to take turns to come to the surface to breathe. During four days of rehearsal, Jason $\mathrm{Wu}$ stayed in the water over 
10 hours every day. To move freely and naturally in the water, he practiced by tying a lump of lead to his body, but almost killed himself because it was too heavy, and he dived too fast. In the fast-paced car scenes in the narrow streets of the slum, Jason hangs onto the car using only one arm, which was extremely dangerous. He also gained experience by training with the special troops for ten months to be able to finish the exciting gunfight scenes. In the breathtaking 5 minutes bare-handed battle with Frank Grillo, he gave up using the routine motions and played himself, in person, for every scene, without any stand-ins, stunts, or special effects, and every punch was directed to his body. The way the airplanes, tanks and off-road vehicles were blasted gave moviegoers very strong and realistic visual experiences, but Jason $\mathrm{Wu}$ became deaf in one ear temporarily during shooting. While filming the blast scenes, the temporary deafness phenomenon happened to many of the crew, but everyone carried on. In the "tank version" of the Fast and Furious scene, the actors bravely carried on even when they found that the tanks were leaking and they were likely to explode at any time.

Wu Gang, who is famous for the character Secretary Da Kang, played the veteran in the film and this is his first action film. In order to better present the military image, he was required to join military training to learn combat actions and the use of weapons. He even spent more than 20 days learning nothing but how to hold a gun. On average, he spent over 10 hours holding the submachine gun that weighed 10 kilos, finally changing from someone who knew nothing about guns to almost a weapon expert who can change a clip with a single hand. He got injured many times, taking painkillers to finish all the scenes in an effort not to slow down the shooting progress. His working attitude deserves our respect. Zhang Han, who plays the "rich second generation" Zhuo Yifan, also learnt military tactics and received training by watching military induction videos, which enabled him to transform from "the spoilt brat" into a real soldier. Based on their favorable collaboration in Wolf Warrior, Ju Nan, who played Long Xiaoyun, joined the crew again. $\mathrm{Lu}$ Jingshan, who collaborated with Jason $\mathrm{Wu}$ for the second time, finished 10 months of shooting without taking a stunt double. In order to be able to meet the film's tight production schedule, Yu Qian, who perfectly played the character of a "profiteer," had to miss the performance of his own shows at Deyun Crosstalk Association. With strong determination, under Jason Wu's leadership, everyone contributed with all his/her passion to the accomplishment of such a high-quality film, which eventually led to a box office miracle.

\section{The cultural value of the nation-state promoted the film-viewing experience}

The national cinema has long been the carrier of national cultural identity, and it has often projected national mainstream ideology. Chinese national cinema, at a certain level, also contributes to the "soft power" (national image) of 
China on the international stage. In recent years, mainstream films such as The Taking of Tiger Mountain (880 million yuan box office), Operation Mekong (1.18 billion yuan box office) and The Founding of an Army (400 million yuan box office) have gained tremendous market influence. The Wolf Warrior series, which are mainstream films, have artfully combined the commercial elements with mainstream ideologies in a typical military action film genre. The continuous upgrading of advanced military weapons in the film from bare-handed combat, gunfire to rocket projectiles; and from drones, tanks to warships has impressed the viewers and accomplished a Chinese version of The Expendables, Band of Brothers or Saving Private Ryan. As expected, the Wolf Warrior series has developed a "tough man" culture with strong confidence and determination, which matches the individualistic heroism in the superhero series in American Marvel comics or detective comics. China has hence created its own patriotic and courageous superhero films. In the Wolf Warrior series, the core theme is: "Anyone who offends China will be punished, no matter how far away he is." This follows the national mentality of the contemporary development phase of China and provides people with an emotional outlet.

In Wolf Warrior 2, the cross-border emotional resonance between Leng Feng and the refugees deeply moved the viewers whose sense of honor and pride rose up when Leng Feng raised the national flag and went through the war zone in Africa without any hindrance. The last scene of the film is a picture of a Chinese passport, on the back of which is written: "Citizens of the People's Republic of China: when you encounter danger abroad, please do not give up, because there is a strong China behind you." This is an announcement to the Chinese people around the world that a Chinese passport may not take you everywhere in the world, but it can surely rescue you from every corner of the world. This is the scene that touches its viewers and even made them cry. Most Chinese people feel proud and excited about a strong China, and their patriotism is ultimately inspired by these touching scenes, which has developed a new realm for film language and tapped into the mainstream emotions.

The domestic film industry is still immature. Except for some low-cost romantic films, comedies, literary films and youth films which have gained a place in the market, the so-called blockbuster is still crossing the river by feeling the stones. The domestic film breakthrough of Wolf Warrior 2 is taking the initiative of the Chinese blockbuster and also marks the beginning of prosperity for Chinese film exports. Wolf Warrior 2 is the first military action film that was distributed and screened in an overseas market. Essentially, the fundamental purpose of film exports is to give domestic film production the ability to communicate with the world and to make an authentic international cultural product. The biggest success of Wolf Warrior 2 is not its 5.68 billion yuan box office but the opening of a new era, and it sends out a strong signal that we can make remarkable Chinese blockbusters that can be 


\section{Chao Yu}

popular internationally. We believe that Wolf Warrior 2 is an opportunity. As long as we carry both the industrial and craftsmanship spirit, and keep the film industry developing in a healthy way, China will eventually transform from a country with a large number of film audiences to a country with high quality of film productions. 